\title{
Perception Based Study of Variation Order in Building Construction Projects
}

\section{Anjay Kumar Mishra ${ }^{1}$, Neetu Korala ${ }^{2}$, Sujan Khadka ${ }^{2}$, Amit Dhungana ${ }^{2}$, Rajat}

Pokharel $^{2}$, Shangrila Lama ${ }^{2}$, Niraj Adhikari ${ }^{2}$, Shubash Acharya ${ }^{2}$ \& P. S. Aithal ${ }^{3}$

${ }^{1}$ Associate Professor, Madan Bhandari Memorial Academy Nepal, Urlabari-3, Morang, Nepal

OrcidID: 0000-0003-2803-4918; Email: anjaymishra2000@ gmail.com

${ }^{2}$ Master's Scholars, Madan Bhandari Memorial Academy Nepal, Urlabari-3, Morang, Nepal

E-mail: neetukoirala2072@gmail.com; E-mail: sujankhadka2052@gmail.com,

E-mail: dhungana.amit1000@ gmail.com,; E-mail: rajatpokhrel@gmail.com,

E-mail: shangrilalama29@gmail.com,;E-mail: adhniraj@gmail.com

E-mail: subas24acharya94@gmail.com

${ }^{3}$ College of Management \& Commerce, Srinivas University, Mangalore, India

OrcidID: 0000-0002-4691-8736; E-mail: psaithal@ gmail.com

Area/Section: Project Management.

Type of the Paper: Policy Research.

Type of Review: Peer Reviewed as per $|\mathrm{C}| \mathrm{O}|\mathrm{P}| \mathrm{E} \mid$ guidance.

Indexed in: OpenAIRE.

DOI: https://doi.org/10.5281/zenodo.5152781

Google Scholar Citation: IJMTS

\section{How to Cite this Paper:}

Mishra, Anjay Kumar, Neetu Korala, Sujan Khadka, Amit Dhungana, Rajat Pokharel, Shangrila Lama, Niraj Adhikari, Shubash Acharya \& Aithal, P. S., (2021). Perception Based Study of Variation Order 15278in Building Construction Projects. International Journal of Management, Technology, and Social Sciences (IJMTS), 6(2), 12-27. DOI: https://doi.org/10.5281/zenodo.5152781

International Journal of Management, Technology, and Social Sciences (IJMTS)

A Refereed International Journal of Srinivas University, India.

CrossRef DOI: https://doi.org/10.47992/IJMTS.2581.6012.0150

(C) With Author.

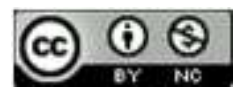

This work is licensed under a Creative Commons Attribution-Non-Commercial 4.0 International License subject to proper citation to the publication source of the work.

Disclaimer: The scholarly papers as reviewed and published by the Srinivas Publications (S.P.), India are the views and opinions of their respective authors and are not the views or opinions of the SP. The SP disclaims of any harm or loss caused due to the published content to any party. 


\title{
Perception Based Study of Variation Order in Building Construction Projects
}

\author{
Anjay Kumar Mishra', Neetu Korala ${ }^{2}$, Sujan Khadka², Amit Dhungana ${ }^{2}$, Rajat \\ Pokharel $^{2}$, Shangrila Lama ${ }^{2}$, Niraj Adhikari², Shubash Acharya ${ }^{2}$ \& P. S. Aithal ${ }^{3}$ \\ ${ }^{1}$ Associate Professor, Madan Bhandari Memorial Academy Nepal, Urlabari-3, Morang, Nepal \\ OrcidID: 0000-0003-2803-4918; Email: anjaymishra2000@ gmail.com \\ ${ }^{2}$ Master's Scholars, Madan Bhandari Memorial Academy Nepal, Urlabari-3, Morang, Nepal \\ E-mail: neetukoirala2072@ gmail.com;E-mail: sujankhadka2052@gmail.com. \\ E-mail: dhungana.amit1000@ gmail.com,; E-mail: rajatpokhrel@gmail.com, \\ E-mail: shangrilalama29@gmail.com,;E-mail: adhniraj@gmail.com \\ E-mail: subas24acharya94@ gmail.com \\ ${ }^{3}$ College of Management \& Commerce, Srinivas University, Mangalore, India \\ OrcidID: 0000-0002-4691-8736; E-mail: psaithal@ gmail.com
}

\begin{abstract}
Purpose: The main objective of this study is to identify the various origin and causes of variation orders. The study area is limited to Tribhuwan University premises, Kathmandu. The result of this study can be further used to analyze the impacts of those and also to develop prevention measures which further can be beneficial in upcoming projects.

Design/Methodology/Approach: Fifty respondents including client, consultant, and contractor and their representatives having experience above two years were questioned for the primary source of data collection. Research works, papers, publications, journals, online information, contract documents, letters, and documents were used for secondary data collection. For ranking the perception based relative importance index of respondents views of causes, five ranking Likert scale have been used.

Findings/Result: Respondents have viewed the major cause of variations originated from the client in overall projects are change of plans, impediment in prompt decision making, financial difficulties, changes of scope and poor project objectives with RII 0.80, 0.72, 0.69, 0.64, and 0.63 respectively. Similarly, the causes originated from consultants are change of plans or scope, defects in the bill of quantities, change in design, defect in design, and lack of judgment and experience with RII 0.756, 0.736, 0.712, 0.668, and 0.656 respectively. Major causes having their origin from the contractor are found to be lack of specified and appropriate competent construction manager, lack of involvement in design, lack of judgement and experience, lack of strategic planning, and financial difficulties with RII 0.72, 0.70, 0.66, 0.66, and 0.59 respectively. Another main cause of weather conditions with RII 0.55 and the least is socio-cultural factors having RII 0.43.
\end{abstract}

Originality/Value: It is action research to enhance the performance of Projects by managing Variations.

Paper Type: Analytical Policy Research

Keywords: Variation order, Client, Consultant, Contractor, Causes, Measures

\section{INTRODUCTION :}

In Nepal, most of the building constructions are increasing rapidly after Gorkha Earthquake [1]. Some of the projects are uncertain even after many years of start due to dispute, arbitration, and other many causes [2]. There is always a variation order that occurs during the progress of the ongoing construction projects. This will somehow increase the cost and duration of the project and will affect the development of the project. An increase in the additional value of the cost and duration is waste and this will cause problems towards the contractors, consultants, and clients [3]. This study is beneficial to understand the present status of project completion time and project cost of building construction projects. This study

Anjay Kumar Mishra, et al, (2021); www.srinivaspublication.com 
is supposed to provide clear and concise views regarding the causes of variation orders of building construction in the perspective of cost and duration of the completion of the project.

The study mainly focuses in exploring a preventive approach to eliminate or reduce the complexity created by variation orders during construction in successful completion of project remaining within the premises of the timeframe and the available budget. The research is expected to provide the developers, designers, consultants and the contractors regarding the knowledge and idea of the problems that can arise during construction phase due to variation orders issued by any of the related parties. This helps the related stakeholders to plan a proactive approach to find a solution regarding the delay and cost overrun due to non-value adding activities like variation orders. Therefore, this study intended to identify the causes of variation orders; analyze the causes and factors of those variation orders of building construction. Also preventing measures to eliminate or reduce those variation orders.

\section{OBJECTIVES :}

The general objective of the study is to assess causes of variation orders along with factors and measures to manage for effective project performance improvement.

\section{LITERATURE REVIEW :}

\subsection{Time Overrun of Construction Project:}

Research done earlier indicates that "changed work complicates a project and invites delays" (Mishra and Aithal) [4]. Ghimire and Mishra (2019) [5] stated that construction delays are often result from miscommunication between contractors, subcontractors, owners, and suppliers. Time and cost overrun may not be prevented from entering but the evolving new technology like BIM, new methods, and past experience could be used to reduce the impact from recognized risk factors, particularly in the undeveloped and developing countries (Yadav and Mishra) [6].

Time Overrun is one of the most significant issues being faced by the construction industry today. There are various factors responsible for the time overrun which requires serious attention to understand and address in order to achieve successful completion of projects on time. This is because time overrun has a great impact on construction cost which can never be recovered (Mishra et al, 2020) [7].

\subsection{Provision for Time Extension Public Procurements of Nepal:}

Variation is a necessary evil as it cannot be accurately stated everything without implementation. So, variation is taking place though it is not beneficial in all cases. According to Neetu et al (2021) [3], it is presumed that variety orders have expanded the venture cost. The significant reasons for variety orders affecting venture cost are extra work, customer monetary issues/delay in an installment of the bill, and change in plan. Reasons for variety of orders affecting venture time are change in plan, delay in installment and question between gatherings to the agreement. These significant reasons for varieties are started from the customer and expert. The worker for hire related reasons for variety are absence of determined and fitting skillful development chief, absence of inclusion in plan and absence of judgment and experience. A beneficial variation request is the one that is given to work on the quality, the norm, the expense decrease, the timetable and furthermore level of trouble in that venture. This kind of variety request is started for esteem investigation purposes to understand the harmony between the expense, then, at that point usefulness and furthermore the sturdiness parts of the undertaking so the customer is fulfilled. This variety request likewise disposes of pointless expense from a task so the customer's advantages against the asset's information can be optimized. An inconvenient variety request is characterized as a variety request that contrarily affects the customer's worth and their venture execution. Unfavorable variety request compromises the customer's worth framework. A customer who is encountering a monetary issue may substitute their materials of quality standard costly materials to unacceptable modest materials. For instance, a development project that is arranged in a pungent climate, steel oxidation will happen to the steel window outline in case it is picked as the material to construct the window outlines rather than wood or aluminum outlines. Variation and price adjustment are not the same but both are creating issue for project success [8].

\section{RESEARCH METHODOLOGY :}

\subsection{Selection of Study Area:}


This research is focused on the study of origin and causes of variation orders in building construction in Kirtipur Municipality especially inside Tribhuvan University premises. After Gorkha Earthquake Tribhuvan University has completed 5 contracts with name Construction of Mathematical Sciences Building at TU, Kirtipur, Construction of Vice Chancellor Building at TU, Kirtipur, Construction of Medical college and Teaching Hospital Building at TU, Kirtipur, Construction of Management Dean Office at TU, Kirtipur and Construction of Rector Office at TU, Kirtipur.

\subsection{Research Approach:}

The research was based on both qualitative and quantitative approach. The research was analytical research. Direct analysis of the bills of quantity, bills approved by the client for payment, letters and similar documents were analyzed. Similarly, questionnaire survey was carried out with structured and semi- structured questions regarding the research objectives.

\subsection{Study population:}

The respondents are client, consultant, contractor and their representatives. In each of the five projects, two respondents were from client and client representatives, three were from consultants' side and five were from contractor's side. Altogether 50 were questioned. Among them 12 participants had an experience of 2 to 5 yrs, 14 participants had 5 to 10 years of experience, 13 had 10 to $15 \mathrm{yrs}$ of experience, 5 had 15 to 20 yrs of experience and 6 had an experience above 20 years.

\subsection{Data collection:}

The following are the data collection tools were used during this research:

- Field observation and site visit

- Review of documents regarding project and contract

- Questionnaire survey

Original data, i.e., primary data were collected through observations and questionnaire. General questions were asked to the participants. The secondary data were collected through research papers, publications, online medium, contract documents, letters and documents.

\subsection{Data Analysis:}

This study used both qualitative and quantitative data. The collected data were presented on the basis of quality and the nature of data. Both the data were analyzed and quantitative data was presented in table while logical sequence was developed with qualitative data.

Relative importance index (RII) of each cause was computed and analyzed to determine their respective rank. The formula used is as follows:

$\mathrm{RII}=\Sigma \mathrm{W} /\left(\mathrm{A}^{*} \mathrm{~N}\right) \ldots \ldots \ldots \ldots \ldots \ldots \ldots$.

Where, RII= Relative Importance Index

$\mathrm{W}=$ scale for weight in the scale (ranges from 1 to 5 )

$\mathrm{A}=$ the highest weight of the scale (equal to 5)

$\mathrm{N}=$ total number of respondents concerning each factor

We used Likert- type scale in analyzing qualitative data which were obtained from the questionnaires, suitable for ranking the statements of respondents' views by using the relative importance scale (RII). As responded by the respondents, for each cause RII was calculated and overall ranking of the causes of variation orders was determined. The Causes of variation orders were tabulated with respective to their origin; client, consultant and contractor and ranking of causes with respective to their origin was also developed which provided a clear picture of the causes of variation order; with respect to the origin of variation orders and also in overall.

\subsection{Validity and Reliability;}

The validity of content, construct and face have been assured through triangulation and pretest and comparison with literature provides reliability.

\section{RESULTS AND DISCUSSION :}

\subsection{Identification of variation orders inside Tribhuvan University premises:}


Table 1: List of variation of works in projects

\begin{tabular}{|c|c|l|l|}
\hline $\begin{array}{l}\text { S } \\
\text { No }\end{array}$ & Project & Variation of works & $\begin{array}{l}\text { Variation } \\
\text { Type }\end{array}$ \\
\hline 1 & Project 1 & Quantity of RCC and formwork increased & Addition \\
\hline \multirow{3}{*}{2} & \multirow{2}{*}{ Project 2 } & Quantity of RCC, formwork and rebar increased & Addition \\
\cline { 3 - 4 } & & Addition of retaining wall works & Addition \\
\cline { 3 - 4 } & Addition of truss and roofing works & Addition \\
\hline \multirow{2}{*}{3} & \multirow{2}{*}{ Project 3 } & Quantity of earthwork increased & Addition \\
\cline { 3 - 4 } & & Quantity of cement concrete block increased & Addition \\
\hline \multirow{4}{*}{4} & Quantity of earthwork increased & Addition \\
\cline { 3 - 4 } & \multirow{3}{*}{ Project 4 } & Quantity of RCC, formwork and rebar increased & Addition \\
\cline { 3 - 4 } & & Addition of retaining wall works & Addition \\
\cline { 3 - 4 } & & Addition of sanitary fittings and accessories & Addition \\
\cline { 3 - 4 } & & Quantity of brickwork increased & Addition \\
\hline \multirow{3}{*}{5} & Quantity of RCC, formwork and rebar increased & Addition \\
\cline { 3 - 4 } & Project 5 & Scaffolding work and brick cladding works & Addition \\
\cline { 3 - 4 } & & Quantity of brickwork increased & $\begin{array}{l}\text { Alteration } \\
\text { in design }\end{array}$ \\
\hline
\end{tabular}

Table 1 shows the variations occurred in different selected building construction projects inside the Tribhuvan University premises. From the study of the contract documents, interim payment certificates and project related letters, various variation orders have been identified along with their severity to the project. According to the table, it is known that the major variations include addition of various works and also alteration of works from initial design.

\subsection{Causes of variation orders in different selected projects:}

Table 2 : Causes of variation orders originated from client

(Combined view of respondents: client, consultant and contractor)

\begin{tabular}{|c|c|c|c|c|c|c|c|c|c|c|c|c|c|}
\hline \multirow[b]{2}{*}{ S. No. } & \multirow{2}{*}{ Causes of variation order } & \multicolumn{2}{|c|}{ 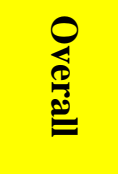 } & \multicolumn{2}{|c|}{$\begin{array}{l}7 \\
\stackrel{0}{0} \\
\stackrel{0}{2} \\
-\end{array}$} & \multicolumn{2}{|c|}{ 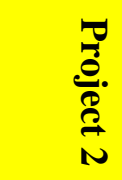 } & \multicolumn{2}{|c|}{ 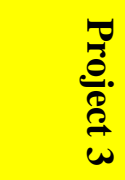 } & \multicolumn{2}{|r|}{ 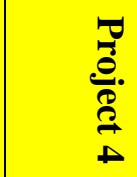 } & \multicolumn{2}{|c|}{ 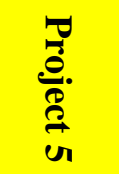 } \\
\hline & & 元 & 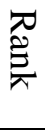 & 互 & $\begin{array}{l}\pi_{0} \\
\tilde{\mathscr{V}}_{2}\end{array}$ & 元 & $\begin{array}{l}\pi_{0} \\
\tilde{D}_{\vec{\lambda}}\end{array}$ & 䀔 & 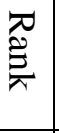 & 疋 & 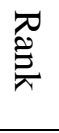 & 元 & 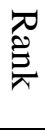 \\
\hline 1 & Change of plans & 0.80 & 1 & 0.76 & 1 & 0.84 & 1 & 0.80 & 1 & 0.88 & 1 & 0.70 & 1 \\
\hline 2 & Impediment in prompt decision making & 0.72 & 2 & 0.76 & 2 & 0.60 & 5 & 0.70 & 2 & 0.84 & 2 & 0.70 & 2 \\
\hline 3 & Financial difficulties & 0.69 & 3 & 0.76 & 3 & 0.76 & 3 & 0.68 & 3 & 0.60 & 4 & 0.50 & 5 \\
\hline 4 & Change of scope & 0.64 & 4 & 0.60 & 5 & 0.80 & 2 & 0.60 & 5 & 0.58 & 5 & 0.60 & 3 \\
\hline 5 & Poor project objectives & 0.63 & 5 & 0.68 & 4 & 0.56 & 6 & 0.62 & 4 & 0.68 & 3 & 0.60 & 4 \\
\hline 6 & Change in schedule & 0.52 & 6 & 0.48 & 8 & 0.62 & 4 & 0.58 & 6 & 0.54 & 6 & 0.40 & 8 \\
\hline 7 & Change in materials and procedure & 0.49 & 7 & 0.52 & 6 & 0.46 & 8 & 0.54 & 7 & 0.50 & 7 & 0.44 & 6 \\
\hline 8 & Change in specification & 0.46 & 8 & 0.50 & 7 & 0.56 & 7 & 0.44 & 8 & 0.40 & 8 & 0.42 & 7 \\
\hline
\end{tabular}

Table 2 shows that based on the analysis of the combined views of construction team and analysis of causes of variations originated from client in project 1 , the major causes are found to be change of plans, financial difficulties, impediment in prompt decision making, poor project objectives and change of scope with RII 076, 0.76, 0.76, 0.68 and 0.60 respectively. Least important cause is change in schedule with RII 0.48 .

Similarly, table 2 indicates that based on the combined views of construction team and analysis of causes of variation originated from client in project 2, the major causes are found to be change of plans, change of scope, financial difficulties, change in schedule and impediment in prompt decision making 
with RII $0.84,0.80,0.76,0.62$ and 0.60 respectively. Least important cause is change in materials and procedure with RII 0.46 .

Table 2 reveals that based on the combined views of construction team and analysis of causes of variation originated from client in project 3, the major causes are found to be change of plans, impediment in prompt decision making, financial difficulties, change in schedule, poor project objectives and changes of scope with RII $0.80,0.70,0.68,0.62$ and 0.60 respectively. Least important cause is change in specification with RII 0.44 .

Table 2 shows that based on the combined views of construction team and analysis of causes of variation originated from client in project 4 , the major causes are found to be change of plans, impediment in prompt decision making, poor project objectives, financial difficulties and changes of scope with RII $0.88,0.84,0.68,0.6$ and 0.58 respectively. Least important cause is change in specification with RII 0.40 .

Table 2 shows that based on the combined views of construction team and analysis of causes of variation originated from client in project 5 , the major causes are found to be change of plans, impediment in prompt decision making, changes of scope, poor project objectives and financial difficulties with RII $0.70,0.70,0.60,0.60$ and 0.5 respectively. Least important cause is change in schedule with RII 0.40 .

The overall results show that based on the analysis of combined views of respondents' client, consultant and contractor, the major causes of variations originated from client in overall projects are found to be change of plans, impediment in prompt decision making, financial difficulties, change of scope and poor project objectives with RII $0.80,0.72,0.69,0.64$ and 0.63 respectively. Least important cause is change in specification with RII 0.46 . All of the projects have been suffered from major causes of variations, that is change of plans, impediment in prompt decision making by client which have led to the variation in the construction projects.

Table 3: Causes of variation orders originated from consultant

(Combined view of respondents: client, consultant and contractor)

\begin{tabular}{|c|c|c|c|c|c|c|c|c|c|c|c|c|c|}
\hline \multirow[b]{2}{*}{$\begin{array}{l}\text { S. } \\
\text { No. }\end{array}$} & \multirow{2}{*}{$\begin{array}{c}\text { Causes of variation } \\
\text { order }\end{array}$} & \multicolumn{2}{|c|}{$\begin{array}{l}0 \\
0 \\
0\end{array}$} & \multicolumn{2}{|r|}{$\begin{array}{l}\frac{9}{0} \\
\stackrel{0}{0} \\
\stackrel{0}{2}\end{array}$} & \multicolumn{2}{|r|}{$\frac{7}{2}$} & \multicolumn{2}{|r|}{ 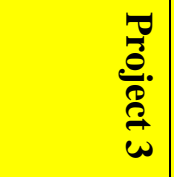 } & \multicolumn{2}{|r|}{ 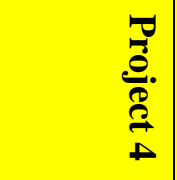 } & \multicolumn{2}{|c|}{ 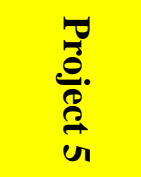 } \\
\hline & & 元 & $\begin{array}{l}\bar{Z} \\
\tilde{E}_{\pi}\end{array}$ & 元 & 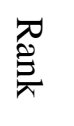 & 元 & 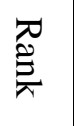 & 互 & 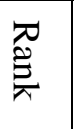 & 즙 & 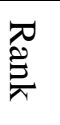 & 䀔 & 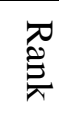 \\
\hline 1 & $\begin{array}{l}\text { Change of plans or } \\
\text { scope }\end{array}$ & 0.756 & 1 & 0.64 & 8 & 0.82 & 1 & 0.84 & 1 & 0.8 & 1 & 0.68 & 1 \\
\hline 2 & $\begin{array}{l}\text { Defects in bill of } \\
\text { quantities }\end{array}$ & 0.736 & 2 & 0.72 & 1 & 0.76 & 2 & 0.74 & 2 & 0.8 & 2 & 0.66 & 3 \\
\hline 3 & Change in design & 0.712 & 3 & 0.70 & 2 & 0.70 & 4 & 0.68 & 5 & 0.8 & 3 & 0.68 & 2 \\
\hline 4 & Defect in design & 0.668 & 4 & 0.66 & 5 & 0.72 & 3 & 0.66 & 7 & 0.76 & 4 & 0.54 & 15 \\
\hline 5 & $\begin{array}{l}\text { Lack of judgment } \\
\text { and experience }\end{array}$ & 0.656 & 5 & 0.68 & 4 & 0.58 & 9 & 0.66 & 9 & 0.76 & 5 & 0.60 & 8 \\
\hline 6 & $\begin{array}{l}\text { Non-compliance of } \\
\text { design with owners } \\
\text { requirement }\end{array}$ & 0.632 & 6 & 0.58 & 11 & 0.62 & 6 & 0.64 & 10 & 0.66 & 7 & 0.66 & 4 \\
\hline 7 & $\begin{array}{l}\text { Conflicts between } \\
\text { contract documents }\end{array}$ & 0.608 & 7 & 0.56 & 14 & 0.50 & 17 & 0.72 & 3 & 0.66 & 6 & 0.60 & 6 \\
\hline 8 & $\begin{array}{l}\text { Errors and omissions } \\
\text { in design }\end{array}$ & 0.608 & 8 & 0.68 & 3 & 0.64 & 5 & 0.58 & 15 & 0.58 & 13 & 0.56 & 12 \\
\hline 9 & $\begin{array}{l}\text { Inadequate working } \\
\text { drawing detail }\end{array}$ & 0.604 & 9 & 0.66 & 7 & 0.58 & 8 & 0.70 & 4 & 0.48 & 19 & 0.60 & 7 \\
\hline 10 & Lack of coordination & 0.596 & 10 & 0.62 & 9 & 0.60 & 7 & 0.68 & 6 & 0.56 & 14 & 0.52 & 17 \\
\hline 11 & $\begin{array}{l}\text { Impediment in } \\
\text { prompt decision } \\
\text { making process }\end{array}$ & 0.588 & 11 & 0.66 & 6 & 0.50 & 18 & 0.66 & 8 & 0.60 & 12 & 0.52 & 16 \\
\hline 12 & Design complexity & 0.580 & 12 & 0.54 & 15 & 0.56 & 10 & 0.62 & 12 & 0.62 & 8 & 0.56 & 11 \\
\hline
\end{tabular}




\begin{tabular}{|c|l|c|c|c|c|c|c|c|c|c|c|c|c|}
\hline 13 & $\begin{array}{l}\text { Inadequate site } \\
\text { investigation }\end{array}$ & 0.576 & 13 & 0.58 & 10 & 0.56 & 11 & 0.50 & 24 & 0.62 & 9 & 0.62 & 5 \\
\hline 14 & $\begin{array}{l}\text { Obstinate nature of } \\
\text { consultant }\end{array}$ & 0.568 & 14 & 0.50 & 19 & 0.56 & 12 & 0.64 & 11 & 0.62 & 10 & 0.52 & 18 \\
\hline 15 & Technology change & 0.540 & 15 & 0.50 & 20 & 0.48 & 22 & 0.58 & 17 & 0.58 & 14 & 0.56 & 13 \\
\hline 16 & Value engineering & 0.540 & 16 & 0.48 & 22 & 0.48 & 23 & 0.56 & 19 & 0.62 & 11 & 0.56 & 14 \\
\hline 17 & Ambiguous design & 0.536 & 17 & 0.56 & 12 & 0.50 & 16 & 0.54 & 20 & 0.52 & 17 & 0.56 & 9 \\
\hline 18 & $\begin{array}{l}\text { Change of schedule } \\
\text { Short comings in } \\
\text { contractual pricing } \\
\text { documents }\end{array}$ & 0.528 & 18 & 0.56 & 13 & 0.48 & 21 & 0.54 & 21 & 0.50 & 18 & 0.56 & 10 \\
\hline 20 & $\begin{array}{l}\text { Inadequate scope of } \\
\text { work for contractor }\end{array}$ & 0.496 & 20 & 0.52 & 17 & 0.44 & 24 & 0.62 & 13 & 0.44 & 20 & 0.46 & 19 \\
\hline 21 & $\begin{array}{l}\text { Lack of knowledge } \\
\text { of available material }\end{array}$ & 0.492 & 21 & 0.48 & 21 & 0.54 & 13 & 0.56 & 18 & 0.44 & 21 & 0.44 & 20 \\
\hline 22 & Lack of required data & 0.488 & 22 & 0.52 & 18 & 0.50 & 19 & 0.60 & 14 & 0.44 & 22 & 0.38 & 24 \\
\hline 23 & $\begin{array}{l}\text { Change in } \\
\text { specification }\end{array}$ & 0.484 & 23 & 0.52 & 16 & 0.52 & 15 & 0.54 & 22 & 0.42 & 23 & 0.42 & 23 \\
\hline & $\begin{array}{l}\text { Non-compliance of } \\
\text { design with } \\
\text { government } \\
\text { regulation }\end{array}$ & 0.464 & 24 & 0.42 & 24 & 0.54 & 14 & 0.52 & 23 & 0.40 & 24 & 0.44 & 21 \\
\hline
\end{tabular}

Table 3 shows that based on the combined views of construction team and analysis of causes of variation originated from consultant in project 1, the major causes are found to be defects in bill of quantities, change in design, error and omissions in design, lack of judgment and experience and defect in design with RII $0.72,0.70,0.68,0.68$ and 0.66 respectively. Least important cause is non-compliance of design with government regulation with RII 0.42 .

Similarly, table 3 indicates that based on the combined views of construction team and analysis of causes of variation originated from consultant in project 2, the major causes are found to be change of plans or scope, defects in bill of quantities, defect in design, change in design and error and omissions in design with RII $0.82,0.76,0.72,0.70$ and 0.64 respectively. Least important cause is inadequate scope of work for contractor with RII 0.44 .

Table 3 reveals that based on the combined views of construction team and analysis of causes of variation originated from consultant in project 3 , the major causes are found to be change of plans or scope, defects in bill of quantities, conflicts between contract documents, inadequate working drawing detail and change in design, with RII $0.84,0.74,0.72,0.70$ and 0.68 respectively. Least important cause is inadequate site investigation with RII 0.50 .

Table 3 shows that based on the combined views of construction team and analysis of causes of variation originated from consultant in project 4 , the major causes are found to be change of plans or scope, change in design, defects in bill of quantities, defect in design and lack of judgment and experience with RII $0.80,0.80,0.80,0.76$ and 0.76 respectively. Least important cause is non-compliance of design with government regulation with RII 0.40 .

Similarly, table 3 indicates that based on the combined views of construction team and analysis of causes of variation originated from consultant in project 5, the major causes are found to be change of plans or scope, change in design, defects in bill of quantities, non-compliance of design with owners' requirement and inadequate site investigation with RII $0.68,0.68,0.66,0.66$ and 0.62 respectively. Least important cause is lack of required data with RII 0.38 .

The overall results indicate that based on the combined views of respondents' client, consultant and contractor, the major causes of variations originated from consultant in overall projects, the major causes are found to be change of plans or scope, defects in bill of quantities, change in design, defect in design and lack of judgment and experience with RII 0.756, 0.736, 0.712, 0.668 and 0.656 respectively. Least important cause is non-compliance of design with government regulation with RII 0.464. All of the projects have been suffered from change of plan or scope by consultant which have led to the variation. 
Table 4: Causes of variation orders originated from contractor

(Combined view of respondents: client, consultant and contractor)

\begin{tabular}{|c|c|c|c|c|c|c|c|c|c|c|c|c|c|}
\hline \multirow[b]{2}{*}{$\begin{array}{l}\text { S. } \\
\text { No. }\end{array}$} & \multirow{2}{*}{ Causes of variation order } & \multicolumn{2}{|c|}{$\begin{array}{l}0 \\
0 \\
\stackrel{0}{0}\end{array}$} & \multicolumn{2}{|r|}{ 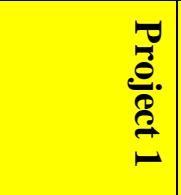 } & \multicolumn{2}{|r|}{ 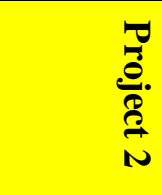 } & \multicolumn{2}{|r|}{ 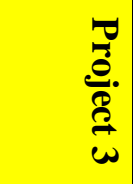 } & \multicolumn{2}{|r|}{ 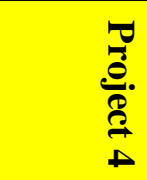 } & \multicolumn{2}{|c|}{$\begin{array}{l}\overrightarrow{0} \\
\frac{0}{2} \\
\frac{3}{4}\end{array}$} \\
\hline & & 元 & 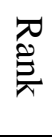 & 元 & 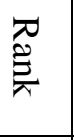 & 元 & $\begin{array}{l}\mathbb{N}^{2} \\
\sum_{\bar{N}}\end{array}$ & 元 & 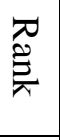 & 元 & 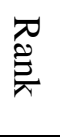 & 元 & $\begin{array}{l}\text { त्र } \\
\hat{\mathscr{V}}_{\pi}\end{array}$ \\
\hline 1 & $\begin{array}{l}\text { Lack of specified and } \\
\text { appropriate competent } \\
\text { construction manager }\end{array}$ & 0.72 & 1 & 0.80 & 1 & 0.66 & 1 & 0.78 & 2 & 0.72 & 3 & 0.58 & 3 \\
\hline 2 & $\begin{array}{l}\text { Lack of involvement in } \\
\text { design }\end{array}$ & 0.70 & 2 & 0.64 & 5 & 0.52 & 7 & 0.82 & 1 & 0.82 & 1 & 0.68 & 1 \\
\hline 3 & $\begin{array}{l}\text { Lack of judgement and } \\
\text { experience }\end{array}$ & 0.66 & 3 & 0.68 & 3 & 0.52 & 8 & 0.74 & 3 & 0.74 & 2 & 0.64 & 2 \\
\hline 4 & Lack of strategic planning & 0.66 & 4 & 0.72 & 2 & 0.66 & 2 & 0.68 & 5 & 0.66 & 4 & 0.54 & 4 \\
\hline 5 & Financial difficulties & 0.59 & 5 & 0.60 & 7 & 0.60 & 4 & 0.66 & 6 & 0.58 & 7 & 0.48 & 8 \\
\hline 6 & Differing site condition & 0.58 & 6 & 0.64 & 4 & 0.56 & 6 & 0.58 & 8 & 0.60 & 6 & 0.52 & 5 \\
\hline 7 & Desired profitability & 0.56 & 7 & 0.54 & 9 & 0.60 & 3 & 0.70 & 4 & 0.66 & 5 & 0.50 & 7 \\
\hline 8 & Defective workmanship & 0.53 & 8 & .62 & 6 & 0.56 & 5 & 0.58 & 7 & 0.46 & 12 & 0.42 & 11 \\
\hline 9 & $\begin{array}{l}\text { Shortage of skilled } \\
\text { manpower }\end{array}$ & 0.53 & 9 & 0.52 & 10 & 0.52 & 9 & 0.56 & 10 & 0.58 & 8 & 0.46 & 9 \\
\hline 10 & Poor procurement process & 0.52 & 10 & 0.60 & 8 & 0.44 & 11 & 0.58 & 9 & 0.52 & 11 & 0.44 & 10 \\
\hline 11 & $\begin{array}{l}\text { Complex design and } \\
\text { technology }\end{array}$ & 0.51 & 11 & 0.46 & 11 & 0.50 & 10 & 0.54 & 12 & 0.54 & 9 & 0.52 & 6 \\
\hline 12 & $\begin{array}{l}\text { Unfamiliarity with local } \\
\text { condition }\end{array}$ & 0.468 & 12 & 0.46 & 12 & 0.36 & 12 & 0.56 & 11 & 0.54 & 10 & 0.40 & 12 \\
\hline
\end{tabular}

Table 4 shows that based on the combined views of construction team and analysis of causes of variation originated from contractor in project 1 , the major causes originated from contractor are found to be lack of specified and appropriate competent construction manager, lack of strategic planning, lack of judgment and experience, differing site condition and lack of involvement in design with RII 0.80, 0.72, $0.68,0.64$ and 0.64 respectively. Least important cause is unfamiliarity with local condition with RII 0.46 .

Similarly, table 4 indicates that based on the combined views of construction team and analysis of causes of variation originated from contractor in project 2, the major causes originated from contractor are found to be lack of specified and appropriate competent construction manager, lack of strategic planning, desired profitability, financial difficulties and defective workmanship with RII 0.66, 0.66 , $0.60,0.60$ and 0.56 respectively. Least important cause is unfamiliarity with local condition with RII 0.36 .

Table 4 reveals that based on the combined views of construction team and analysis of causes of variation originated from contractor in project 3 , the major causes originated from contractor are found to be lack of involvement in design, lack of specified and appropriate competent construction manager, lack of judgment and experience, desired profitability and lack of strategic planning with RII 0.82, 0.78, $0.74,0.70$ and 0.68 respectively. Least important cause is complex design and technology process with RII 0.54 .

Table 4 reveals that based on the combined views of construction team and analysis of causes of variation originated from contractor in project 4 , the major causes originated from contractor are found to be lack of involvement in design, lack of judgment and experience, lack of specified and appropriate competent construction manager, lack of strategic planning and desired profitability with RII $0.82,0.74$, $0.72,0.66$ and 0.64 respectively. Least important cause is defective workmanship with RII 0.46.

On the combined views of construction team and analysis of causes of variation originated from contractor in project 5 , the major causes originated from contractor are found to be lack of involvement 
in design, lack of judgment and experience, lack of specified and appropriate competent construction manager, lack of strategic planning and differing site condition with RII 0.64, 0.64, 0.58, 0.54 and 0.52 respectively. Least important cause is unfamiliarity with local condition with RII 0.40 .

On the combined views of respondents' client, consultant and contractor and analysis of causes of variation originated from contractor in overall project, the major causes are found to be lack of specified and appropriate competent construction manager, lack of involvement in design, lack of judgment and experience, lack of strategic planning and financial difficulties with RII 0.72, 0.70, 0.66, 0.66 and 0.59 respectively. Least important cause is unfamiliarity with local condition with 0.468 . All of the projects have been suffered from lack of specified and appropriate construction manager and lack of involvement in design for contractor which have led to the variation.

Table 5: Causes of variation orders originated from others

(Combined view of respondents: client, consultant and contractor)

\begin{tabular}{|c|c|c|c|c|c|c|c|c|c|c|c|c|c|}
\hline \multirow[b]{2}{*}{ S. No. } & \multirow[t]{2}{*}{ Causes of variation order } & \multicolumn{2}{|c|}{$\begin{array}{l}0 \\
\stackrel{0}{0} \\
\stackrel{0}{=}\end{array}$} & \multicolumn{2}{|r|}{ 물. } & \multicolumn{2}{|c|}{$\begin{array}{l}7 \\
\frac{0}{3} \\
\frac{3}{2} \\
\text { N }\end{array}$} & \multicolumn{2}{|r|}{ } & \multicolumn{2}{|r|}{ 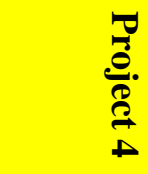 } & \multicolumn{2}{|c|}{$\begin{array}{l}\frac{T}{0} \\
\frac{0}{0} \\
\frac{2}{3} \\
\text { vi }\end{array}$} \\
\hline & & 元 & 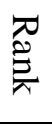 & 元 & $\begin{array}{l}\pi_{0} \\
\tilde{E}_{\lambda}\end{array}$ & 元 & 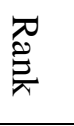 & 元 & $\begin{array}{l}\pi \\
\stackrel{\tilde{Z}}{\pi}\end{array}$ & 元 & $\begin{array}{l}\pi \\
\tilde{\mathscr{V}}_{\pi}\end{array}$ & 즙 & \\
\hline 1 & Weather conditions & 0.55 & 1 & 0.54 & 3 & 0.54 & 1 & 0.62 & 1 & 0.52 & 1 & 0.54 & 1 \\
\hline 2 & $\begin{array}{l}\text { Change in economic } \\
\text { conditions }\end{array}$ & 0.50 & 2 & 0.56 & 2 & 0.52 & 2 & 0.54 & 2 & 0.46 & 3 & 0.40 & 5 \\
\hline 3 & Safety consideration & 0.48 & 3 & 0.46 & 4 & 0.46 & 3 & 0.54 & 3 & 0.50 & 2 & 0.42 & 4 \\
\hline 4 & $\begin{array}{l}\text { Change in government } \\
\text { regulation }\end{array}$ & 0.47 & 4 & 0.58 & 1 & 0.40 & 5 & 0.50 & 4 & 0.44 & 4 & 0.44 & 2 \\
\hline 5 & Socio-cultural factors & 0.43 & 5 & 0.44 & 5 & 0.42 & 4 & 0.48 & 5 & 0.40 & 5 & 0.42 & 3 \\
\hline
\end{tabular}

Table 5 shows that based on the combined views of construction team and analysis of causes of variation originated from others in project 1 , are found to be change in government regulation, change in economic conditions and weather conditions with RII $0.58,0.56$ and 0.54 respectively. Least important cause is socio-cultural factors with RII 0.44 .

Similarly, table 5 reveals that based on the combined views of construction team and analysis of causes of variation originated from others in project 2, the major causes originated from others are found to be weather conditions, change in economic condition and safety consideration with RII $0.54,0.52$ and 0.46 respectively. Least important cause is change in government regulation with RII 0.40 .

On the combined views of construction team and analysis of causes of variation originated from others in project 3, the major causes originated from others are found to be weather conditions, change in economic condition and safety consideration with RII $0.62,0.54$ and 0.54 respectively. Least important cause is socio-cultural factors with RII 0.48 .

On the combined views of construction team and analysis of causes of variation originated from others in project 4, the major causes originated from others are found to be weather conditions, safety consideration and change in economic condition with RII $0.52,0.50$ and 0.46 respectively. Least important cause is socio-cultural factors with RII 0.40.

On the combined views of construction team and analysis of causes of variation originated from others in project 5 , the major causes originated from others are found to be weather conditions, change in government regulation and socio-cultural factors with RII $0.54,0.44$ and 0.42 respectively. Least important cause is change in economic conditions with RII 0.40.

On the combined views of respondents' client, consultant and contractor and analysis of causes of variation originated from others in overall project, the major causes are found to be weather conditions, change in economic conditions and safety consideration. Least important cause is socio-cultural factors with RII 0.43 . Weather condition and change in economic condition also play significant role in occurrence of variation.

\subsection{Causes of variation order impacting project cost:}


Table 6: Causes of variation orders impacting project cost

(Combined view of respondents: client, consultant and contractor)

\begin{tabular}{|c|c|c|c|c|c|c|c|c|c|c|c|c|c|}
\hline \multirow[b]{2}{*}{ S. No. } & \multirow{2}{*}{$\begin{array}{l}\text { Causes of variation orders } \\
\text { impacting project cost }\end{array}$} & \multicolumn{2}{|c|}{ 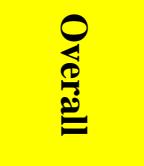 } & \multicolumn{2}{|r|}{$\frac{7}{\stackrel{0}{0}}$} & \multicolumn{2}{|r|}{$\begin{array}{l}\frac{T}{0} \\
\frac{0}{0} \\
\frac{2}{N}\end{array}$} & \multicolumn{2}{|r|}{$\frac{\overrightarrow{0}}{\stackrel{0}{0}}}$. & \multicolumn{2}{|r|}{$\begin{array}{l}\frac{7}{0} \\
\frac{0}{0} \\
\frac{0}{2} \\
\frac{1}{0}\end{array}$} & \multicolumn{2}{|c|}{ 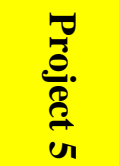 } \\
\hline & & 元 & 冚 & 元 & 元 & 当 & 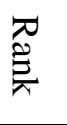 & 元 & 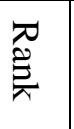 & 邓 & 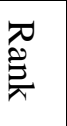 & 元 & 总 \\
\hline 1 & Additional work & 0.800 & 1 & 0.86 & 1 & 0.80 & 1 & 0.70 & 7 & 0.82 & 3 & 0.82 & 1 \\
\hline 2 & $\begin{array}{l}\text { Client's financial problems/ } \\
\text { Delay in payment of bill }\end{array}$ & 0.764 & 2 & 0.70 & 4 & 0.70 & 5 & 0.84 & 1 & 0.84 & 2 & 0.74 & 2 \\
\hline 3 & Change in design & 0.756 & 3 & 0.68 & 5 & 0.78 & 2 & 0.72 & 4 & 0.88 & 1 & 0.72 & 3 \\
\hline 4 & $\begin{array}{l}\text { Force majeure as riots, } \\
\text { strikes, earthquake, etc. }\end{array}$ & 0.728 & 4 & 0.76 & 3 & 0.72 & 4 & 0.72 & 5 & 0.78 & 4 & 0.66 & 4 \\
\hline 5 & $\begin{array}{l}\text { Poor estimate on of original } \\
\text { cost }\end{array}$ & 0.724 & 5 & 0.80 & 2 & 0.70 & 6 & 0.82 & 2 & 0.74 & 6 & 0.56 & 6 \\
\hline 6 & $\begin{array}{l}\text { Incomplete design at the time } \\
\text { of tender }\end{array}$ & 0.672 & 6 & 0.62 & 9 & 0.74 & 3 & 0.70 & 8 & 0.74 & 5 & 0.56 & 5 \\
\hline 7 & $\begin{array}{l}\text { Lack of cost planning/ } \\
\text { monitoring during pre and } \\
\text { post contract stage }\end{array}$ & 0.648 & 7 & 0.62 & 10 & 0.64 & 7 & 0.74 & 3 & 0.70 & 7 & 0.54 & 7 \\
\hline 8 & Time overrun & 0.628 & 8 & 0.62 & 11 & 0.58 & 9 & 0.72 & 6 & 0.68 & 8 & 0.54 & 9 \\
\hline 9 & $\begin{array}{l}\text { Poor project site } \\
\text { management/ Poor cost } \\
\text { control }\end{array}$ & 0.592 & 9 & 0.68 & 6 & 0.56 & 10 & 0.62 & 12 & 0.56 & 11 & 0.54 & 8 \\
\hline 10 & $\begin{array}{l}\text { Change in economic } \\
\text { conditions (e.g. Increase in } \\
\text { cost of raw materials, etc.) }\end{array}$ & 0.584 & 10 & 0.62 & 7 & 0.60 & 8 & 0.62 & 10 & 0.58 & 10 & 0.50 & 10 \\
\hline 11 & Design complexity & 0.564 & 11 & 0.62 & 8 & 0.54 & 11 & 0.62 & 11 & 0.54 & 12 & 0.50 & 12 \\
\hline 12 & Unforeseen problems & 0.564 & 12 & 0.50 & 14 & 0.50 & 15 & 0.66 & 9 & 0.60 & 9 & 0.50 & 13 \\
\hline 13 & $\begin{array}{l}\text { Defective workmanship } \\
\text { (Rework) }\end{array}$ & 0.524 & 13 & 0.56 & 12 & 0.52 & 12 & 0.56 & 13 & 0.48 & 13 & 0.50 & 11 \\
\hline 14 & $\begin{array}{l}\text { Health and safety } \\
\text { considerations }\end{array}$ & 0.492 & 14 & 0.50 & 14 & 0.52 & 14 & 0.54 & 4 & 0.46 & 14 & 0.44 & 15 \\
\hline 15 & Fast track construction & 0.476 & 15 & 0.48 & 15 & 0.52 & 13 & 0.52 & 15 & 0.42 & 15 & 0.44 & 14 \\
\hline
\end{tabular}

Table 6 shows that based on the combined views of construction team and analysis of causes of variation in project 1 , the causes of variation order impacting the project cost are additional work, poor estimate on of original cost, force majeure as riots, strikes, earthquake, etc., client's financial problems/ delay in payment of bill and change in design with RII $0.86,0.80,0.76,0.70$ and 0.68 respectively. Least important cause is fast track construction with RII 0.48.

On the combined views of construction team and analysis of causes of variation in project 2, the causes of variation order impacting the project cost are additional work, change in design, incomplete design at the time of tender, force majeure as riots, strikes, earthquake, etc., and client's financial problems/ delay in payment of bill with RII $0.80,0.78,0.74,0.72$ and 0.70 respectively. Least important cause is unforeseen problems with RII 0.50 .

On the combined views of construction team and analysis of causes of variation in project 3 , the causes of variation order impacting the project cost are client's financial problems/ delay in payment of bill, poor estimate on of original cost, lack of cost planning/ monitoring during pre and post contract stage, change in design and force majeure as riots, strikes, earthquake, etc. with RII 0.84, 0.82, 0.74, 0.72 and 0.72 respectively. Least important cause is fast track construction with RII 0.52 . 
On the combined views of construction team and analysis of causes of variation in project 4, the causes of variation order impacting the project cost are change in design, client's financial problems/ delay in payment of bill, additional work, force majeure as riots, strikes, earthquake, etc., and incomplete design at the time of tender with RII $0.88,0.84,0.82,0.78$ and 0.74 respectively. Least important cause is fast track construction with RII 0.42 .

On the combined views of construction team and analysis of causes of variation in project 5 , the causes of variation order impacting the project cost are additional work, client's financial problems/ delay in payment of bill, change in design, force majeure as riots, strikes, earthquake, etc. and incomplete design at the time of tender with RII $0.82,0.74,0.72,0.66$ and 0.56 respectively. Least important cause is health and safety consideration with RII 0.44 .

On the combined views of client, consultant and contractor and analysis of causes of variation in overall project, the causes of variation order impacting the project cost are additional work, client's financial problems/ delay in payment of bill, change in design, force majeure as riots, strikes, earthquake, etc. and poor estimate on of original cost with RII $0.80,0.764,0.756,0.728$ and 0.724 respectively. Least important cause is fast track construction with RII 0.476 .

\subsection{Causes of variation order impacting project time:}

Table 7: Causes of variation orders impacting project time

(Combined view of respondents: client, consultant and contractor)

\begin{tabular}{|c|c|c|c|c|c|c|c|c|c|c|c|c|c|}
\hline \multirow[b]{2}{*}{ S. No. } & \multirow{2}{*}{$\begin{array}{l}\text { Causes of variation orders } \\
\text { impacting project time }\end{array}$} & \multicolumn{2}{|c|}{ 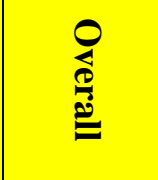 } & \multicolumn{2}{|r|}{$\begin{array}{l}\frac{\pi}{3} \\
\stackrel{0}{0} \\
\stackrel{2}{2}\end{array}$} & \multicolumn{2}{|r|}{$\frac{7}{\frac{0}{0}}$} & \multicolumn{2}{|r|}{$\frac{\overrightarrow{0}}{\frac{0}{0}}}$. & \multicolumn{2}{|r|}{$\frac{7}{0} \frac{0}{0}}$. & \multicolumn{2}{|c|}{$\begin{array}{l}\frac{\pi}{0} \\
\frac{0}{2} \\
\frac{2}{2}\end{array}$} \\
\hline & & 元 & $\begin{array}{l}\overline{0} \\
\tilde{\mathscr{V}}_{\pi}\end{array}$ & 즘 & 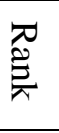 & 元 & 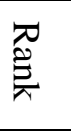 & 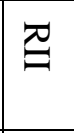 & 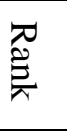 & 元 & 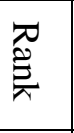 & 百 & 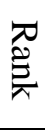 \\
\hline 1 & Change in design & 0.792 & 1 & 0.54 & 7 & 0.78 & 1 & 0.78 & 1 & 0.80 & 1 & 0.74 & 1 \\
\hline 2 & Delay in payment & 0.676 & 2 & 0.56 & 6 & 0.60 & 3 & 0.76 & 2 & 0.76 & 2 & 0.64 & 2 \\
\hline 3 & $\begin{array}{l}\text { Disputes between parties to } \\
\text { the contract }\end{array}$ & 0.616 & 3 & 0.72 & 2 & 0.60 & 4 & 0.62 & 5 & 0.54 & 8 & 0.60 & 4 \\
\hline 4 & $\begin{array}{l}\text { Complaints of one or more of } \\
\text { the parties to the contract }\end{array}$ & 0.612 & 4 & 0.98 & 1 & 0.60 & 2 & 0.58 & 8 & 0.60 & 5 & 0.54 & 6 \\
\hline 5 & Quality standards enhanced & 0.576 & 5 & 0.64 & 4 & 0.48 & 12 & 0.64 & 4 & 0.58 & 7 & 0.60 & 3 \\
\hline 6 & Differing site condition & 0.576 & 6 & 0.64 & 3 & 0.56 & 6 & 0.64 & 3 & 0.620 & 4 & 0.54 & 5 \\
\hline 7 & $\begin{array}{l}\text { Additional specialist } \\
\text { equipment/personnel }\end{array}$ & 0.552 & 7 & 0.60 & 5 & 0.54 & 7 & 0.50 & 12 & 0.58 & 6 & 0.54 & 8 \\
\hline 8 & $\begin{array}{l}\text { Additional health \& safety } \\
\text { equipment/measure }\end{array}$ & 0.544 & 8 & 0.44 & 11 & 0.54 & 8 & 0.52 & 11 & 0.62 & 3 & 0.54 & 9 \\
\hline 9 & Poor procurement process & 0.536 & 9 & 0.54 & 9 & 0.48 & 11 & 0.62 & 6 & 0.52 & 10 & 0.46 & 11 \\
\hline 10 & Optimum cost reduction & 0.508 & 10 & 0.54 & 8 & 0.52 & 9 & 0.56 & 9 & 0.50 & 12 & 0.54 & 7 \\
\hline 11 & Unavailability of equipment & 0.500 & 11 & 0.50 & 10 & 0.50 & 10 & 0.60 & 7 & 0.52 & 11 & 0.44 & 12 \\
\hline 12 & $\begin{array}{l}\text { Unavailability of skilled } \\
\text { manpower }\end{array}$ & 0.496 & 12 & 0.24 & 13 & 0.44 & 13 & 0.56 & 10 & 0.50 & 13 & 0.50 & 10 \\
\hline 13 & Fast track construction & 0.492 & 13 & 0.38 & 12 & 0.58 & 5 & 0.46 & 13 & 0.54 & 9 & 0.38 & 13 \\
\hline
\end{tabular}

Table 7 shows that based on the combined views of construction team in project 1, the causes of variation order impacting the project cost are complaints of one or more of the parties to the contract, disputes between parties to the contract, differing site condition, quality standards enhanced and additional specialist equipment/personnel with RII $0.980,0.720,0.640,0.640$ and 0.60 respectively. The least cause of variation order impacting project time is unavailability of skilled manpower with RII 0.24 .

On the combined views of construction team in project 2 , the causes of variation order impacting the project time are change in design, complaints of one or more of the parties to the contract, delay in payment and disputes between parties to the contract and fast track construction with RII 0.780, 0.680, 
$0.600,0.600,0.600$ and 0.58 respectively. The least cause of variation order impacting project time is unavailability of skilled manpower with RII 0.44 .

On the combined views of construction team in project 3, the causes of variation order impacting the project time are change in design, delay in payment cost overrun, different site condition, quality standard enhanced and disputes between parties to the contract with RII 0.780, 0.760, 0.640, 0.640 and 0.620 respectively with RII 0.46 .

On the combined views of construction team in project 4 , the causes of variation order impacting the project time are change in design, delay in payment, additional health\& safety equipment/measure, differing site condition and complaints of one or more of the parties to the contract with RII 0.80, 0.760, $0.620,0.620$ and 0.60 respectively. The least cause of variation order impacting project time is unavailability of skilled manpower with RII 0.50 .

On the combined views of construction team in project 5 , the causes of variation order impacting the project time are change in design, cost overrun, delay in payment, quality standards enhanced, disputes between parties to the contract and differing site condition with RII 0.74, 0.640, 0.60, 0.60 and 0.54 respectively. The least cause of variation order impacting project time is fast track construction with RII 0.38 .

On the combined views of client, consultant and contractor in overall project, the causes of variation order impacting the project cost are change in design, delay in payment of bill, dispute between parties to the contract complaints of one or more of the parties to the contract and quality standard enhanced with RII $0.792,0.676,0.616,0.612$ and 0.576 respectively. The least cause of variation order impacting project time is fast track construction with RII 0.492 .

5.5 Control measures to minimize variation orders:

Table 8: Control measures to minimize variation orders

(Combined view of respondents: client, consultant and contractor)

\begin{tabular}{|c|c|c|c|c|c|c|c|c|c|c|c|c|c|}
\hline \multirow{2}{*}{ S. No. } & \multirow{2}{*}{$\begin{array}{l}\text { Control measures to minimize } \\
\text { variation orders }\end{array}$} & \multicolumn{2}{|c|}{ 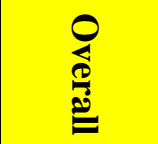 } & \multicolumn{2}{|c|}{ - } & \multicolumn{2}{|c|}{ N } & \multicolumn{2}{|c|}{$\begin{array}{c}\omega \\
\frac{0}{0} \\
\frac{0}{2} \\
2\end{array}$} & \multicolumn{2}{|c|}{$\begin{array}{l}+\frac{7}{0} \\
\frac{0}{2} \\
\frac{0}{3}\end{array}$} & \multicolumn{2}{|c|}{ U } \\
\hline & & 元 & 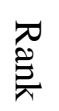 & 互 & 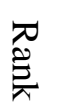 & 元 & $\begin{array}{l}\pi_{0} \\
\hat{E}_{\pi}^{*}\end{array}$ & 元 & 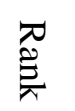 & 元 & 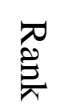 & 元 & 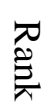 \\
\hline 1 & $\begin{array}{l}\text { Appointment of a specified and } \\
\text { appropriate competent project } \\
\text { manager to supervise design }\end{array}$ & 0.88 & 1 & 0.92 & 1 & 0.74 & 3 & 0.88 & 1 & 0.90 & 1 & 0.96 & 1 \\
\hline 2 & $\begin{array}{l}\text { Preparation of bill of quantity with } \\
\text { good estimate }\end{array}$ & 0.832 & 2 & 0.86 & 3 & 0.90 & 1 & 0.80 & 4 & 0.84 & 2 & 0.76 & 5 \\
\hline 3 & Adequate financial planning & 0.808 & 3 & 0.80 & 4 & 0.80 & 2 & 0.82 & 2 & \begin{tabular}{|l|}
0.80 \\
\end{tabular} & 4 & \begin{tabular}{|l|}
0.82 \\
\end{tabular} & 2 \\
\hline 4 & $\begin{array}{l}\text { Close monitoring (timely monitoring } \\
\text { mechanism) }\end{array}$ & 0.776 & 4 & 0.80 & 6 & 0.70 & 6 & 0.78 & 6 & 0.82 & 3 & 0.78 & 4 \\
\hline 5 & $\begin{array}{l}\text { Use of modern planning techniques } \\
\text { (WBS, CPM, EVA etc.) }\end{array}$ & 0.76 & 5 & 0.80 & 5 & 0.68 & 8 & 0.72 & 9 & 0.78 & 7 & 0.82 & 2 \\
\hline 6 & $\begin{array}{l}\text { Appointment of a specified and } \\
\text { appropriate competent project } \\
\text { manager to supervise construction } \\
\text { phases }\end{array}$ & 0.756 & 6 & 0.92 & 2 & 0.70 & 5 & 0.70 & 10 & 0.72 & 9 & 0.74 & 6 \\
\hline 7 & $\begin{array}{l}\text { Thorough review of designs, } \\
\text { drawings and plans }\end{array}$ & 0.72 & 7 & 0.68 & 13 & 0.74 & 4 & 0.78 & 5 & 0.80 & 6 & 0.60 & 12 \\
\hline 8 & $\begin{array}{l}\text { Full site investigation before and } \\
\text { during construction }\end{array}$ & 0.716 & 8 & 0.78 & 8 & 0.64 & 9 & 0.76 & 7 & 0.76 & 8 & 0.64 & 9 \\
\hline 9 & $\begin{array}{l}\text { Adherence of instruction of } \\
\text { consultant by contractor }\end{array}$ & 0.712 & 9 & 0.74 & 9 & 0.68 & 7 & 0.82 & 3 & 0.68 & 11 & 0.64 & 10 \\
\hline 10 & $\begin{array}{l}\text { Good relation and cooperation by } \\
\text { project parties }\end{array}$ & 0.664 & 10 & 0.70 & 11 & 0.60 & 11 & 0.74 & 8 & 0.66 & 13 & 0.62 & 11 \\
\hline
\end{tabular}




\begin{tabular}{|c|l|c|c|c|c|c|c|c|c|c|c|c|c|}
\hline 11 & $\begin{array}{l}\text { Involvement of contractors during } \\
\text { design phase }\end{array}$ & 0.656 & 11 & 0.56 & 16 & 0.56 & 13 & 0.70 & 11 & 0.80 & 5 & 0.64 & 9 \\
\hline 12 & $\begin{array}{l}\text { Earliest implementation of changes } \\
\text { to avoid delays }\end{array}$ & 0.648 & 12 & 0.68 & 12 & 0.54 & 14 & 0.68 & 12 & 0.70 & 10 & 0.64 & 8 \\
\hline 13 & $\begin{array}{l}\text { Employment of experienced workers } \\
\text { by contractors }\end{array}$ & 0.64 & 13 & 0.78 & 7 & 0.54 & 15 & 0.66 & 15 & 0.66 & 12 & 0.56 & 13 \\
\hline 14 & $\begin{array}{l}\text { Avoidance of miscommunication by } \\
\text { project team }\end{array}$ & 0.604 & 14 & 0.60 & 15 & 0.60 & 10 & 0.66 & 14 & 0.62 & 14 & 0.54 & 14 \\
\hline 15 & $\begin{array}{l}\text { Provision of comprehensive contract } \\
\text { documents to all project parties }\end{array}$ & 0.58 & 15 & 0.74 & 10 & 0.60 & 12 & 0.54 & 16 & 0.50 & 16 & 0.52 & 15 \\
\hline 16 & Use of updated material lists & 0.576 & 16 & 0.68 & 14 & 0.48 & 16 & 0.68 & 13 & 0.58 & 15 & 0.46 & 16 \\
\hline 17 & $\begin{array}{l}\text { Negotiation of change orders by } \\
\text { knowledgeable persons }\end{array}$ & 0.452 & 17 & 0.48 & 18 & 0.38 & 18 & 0.50 & 18 & 0.46 & 17 & 0.44 & 17 \\
\hline 18 & $\begin{array}{l}\text { Improvement of management of } \\
\text { subcontractors to reduce conflicts and } \\
\text { poor coordination between the main } \\
\text { and subcontractors }\end{array}$ & 0.404 & 18 & 0.48 & 17 & 0.40 & 17 & 0.50 & 17 & 0.30 & 18 & 0.34 & 18 \\
\hline
\end{tabular}

Table 8 shows that on the combined views of construction team in project 1 , the major control measures to minimize variation orders are appointment of a specified and appropriate competent project manager to supervise design, appointment of a specified and appropriate competent project manager to supervise construction phase, preparation of bill of quantity with good estimate, adequate financial planning and use of modern planning techniques (WBS, CPM, EVA, etc.) with RII 0.92, 0.92, 0.86, 0.80 and 0.80 respectively. The least control measure to minimize variation order is negotiation of change orders by knowledgeable persons with RII 0.48 .

Similarly, table 8 shows that on the combined views of construction team in project 2 , the major control measures to minimize variation orders are preparation of bill of quantity with good estimate, adequate financial planning, appointment of a specified and appropriate competent project manager to supervise design, thorough review of designs, drawings and plans and appointment of a specified and appropriate competent project manager to supervise construction phase with RII $0.90,0.80,0.74,0.74$ and 0.70 respectively. The least control measure to minimize variation order is negotiation of change orders by knowledgeable persons with RII 0.38 .

Similarly, Table 8 shows that on the combined views of construction team in project 3 , the major control measures to minimize variation orders are appointment of a specified and appropriate competent project manager to supervise design, adequate financial planning, adherence of instruction of consultant by contractor, preparation of bill of quantity with good estimate and thorough review of designs, drawings and plans with RII $0.88,0.82,0.82,0.80$ and 0.78 respectively. The least control measure to minimize variation order is negotiation of change orders by knowledgeable persons with RII 0.50 .

Similarly, Table 8 reveals that on the combined views of construction team in project 4 , the major control measures to minimize variation orders are appointment of a specified and appropriate competent project manager to supervise design, preparation of bill of quantity with good estimate, close monitoring (timely monitoring mechanism), adequate financial planning, and involvement of contractors during design phase with RII $0.90,0.84,0.82,0.80$ and 0.80 respectively. The least important control measure is improvement of management of subcontractors to reduce conflicts and poor coordination between the main and subcontractors with RII 0.30 .

Similarly, table 8 indicates that on the combined views of construction team in project 5 , the control measure to minimize variation order are appointment of a specified and appropriate competent project manager to supervise design, preparation of bill of quantity with good estimate, use of modern planning techniques (WBS, CPM, EVA etc.), adequate financial planning close monitoring (timely monitoring mechanism) and preparation of bill of quantity with good estimate with RII $0.96,0.82,0.82,0.78$ and 0.76 respectively. The least important control measure is improvement of management of subcontractors to reduce conflicts and poor coordination between the main and subcontractors with RII 0.34 . 
Table 9: Control measures to minimize variation orders

(Comparison of overall view of overall client, overall consultant and overall contractor)

\begin{tabular}{|c|c|c|c|c|c|c|c|c|c|}
\hline \multirow[t]{2}{*}{ S. No. } & \multirow{2}{*}{$\begin{array}{c}\text { Control measures to minimize variation } \\
\text { orders }\end{array}$} & \multicolumn{2}{|c|}{ 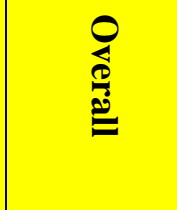 } & \multicolumn{2}{|c|}{ 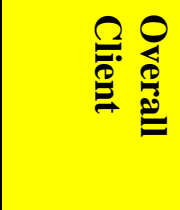 } & \multicolumn{2}{|c|}{ 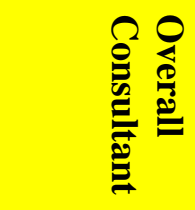 } & \multicolumn{2}{|c|}{ 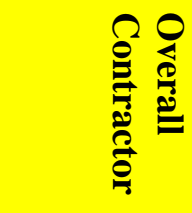 } \\
\hline & & 元 & 总 & 元 & 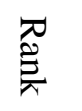 & 冗 & 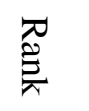 & 冗 & $\begin{array}{l}\pi \\
\stackrel{\tilde{C}}{\pi}\end{array}$ \\
\hline 1 & $\begin{array}{l}\text { Appointment of a specified and } \\
\text { appropriate competent project manager to } \\
\text { supervise design }\end{array}$ & 0.88 & 1 & 0.78 & 4 & 0.960 & 1 & 0.872 & 2 \\
\hline 2 & $\begin{array}{l}\text { Preparation of bill of quantity with good } \\
\text { estimate }\end{array}$ & 0.832 & 2 & 0.82 & 2 & 0.787 & 6 & 0.92 & 1 \\
\hline 3 & Adequate financial planning & 0.808 & 3 & 0.70 & 6 & 0.80 & 5 & 0.856 & 3 \\
\hline 4 & $\begin{array}{l}\text { Close monitoring (timely monitoring } \\
\text { mechanism) }\end{array}$ & 0.776 & 4 & 0.60 & 10 & 0.907 & 2 & 0.776 & 5 \\
\hline 5 & $\begin{array}{l}\text { Use of modern planning techniques (WBS, } \\
\text { CPM, EVA etc.) }\end{array}$ & 0.76 & 5 & 0.64 & 9 & 0.853 & 3 & 0.76 & 6 \\
\hline 6 & $\begin{array}{l}\text { Appointment of a specified and } \\
\text { appropriate competent project manager to } \\
\text { supervise construction phases }\end{array}$ & 0.756 & 6 & 0.86 & 1 & 0.80 & 4 & 0.68 & 14 \\
\hline 7 & $\begin{array}{l}\text { Thorough review of designs, drawings and } \\
\text { plans }\end{array}$ & 0.72 & 7 & 0.64 & 8 & 0.667 & 12 & 0.84 & 4 \\
\hline 8 & $\begin{array}{l}\text { Full site investigation before and during } \\
\text { construction }\end{array}$ & 0.716 & 8 & 0.80 & 3 & 0.707 & 10 & 0.704 & 11 \\
\hline 9 & $\begin{array}{l}\text { Adherence of instruction of consultant by } \\
\text { contractor }\end{array}$ & 0.712 & 9 & 0.66 & 7 & 0.72 & 8 & 0.728 & 8 \\
\hline 10 & $\begin{array}{l}\text { Good relation and cooperation by project } \\
\text { parties }\end{array}$ & 0.664 & 10 & 0.74 & 5 & 0.653 & 14 & 0.728 & 7 \\
\hline 11 & $\begin{array}{l}\text { Involvement of contractors during design } \\
\text { phase }\end{array}$ & 0.656 & 11 & 0.42 & 18 & 0.747 & 7 & 0.728 & 9 \\
\hline 12 & $\begin{array}{l}\text { Earliest implementation of changes to } \\
\text { avoid delays }\end{array}$ & 0.648 & 12 & 0.58 & 11 & 0.68 & 11 & 0.696 & 12 \\
\hline 13 & $\begin{array}{l}\text { Employment of experienced workers by } \\
\text { contractors }\end{array}$ & 0.64 & 13 & 0.54 & 15 & 0.72 & 9 & 0.72 & 10 \\
\hline 14 & \begin{tabular}{|l}
$\begin{array}{l}\text { Avoidance of miscommunication by } \\
\text { project team }\end{array}$ \\
\end{tabular} & 0.604 & 14 & 0.56 & 13 & 0.60 & 15 & 0.688 & 13 \\
\hline 15 & $\begin{array}{l}\text { Provision of comprehensive contract } \\
\text { documents to all project parties }\end{array}$ & 0.58 & 15 & 0.58 & 12 & 0.56 & 16 & 0.552 & 16 \\
\hline 16 & Use of updated material lists & 0.576 & 16 & 0.46 & 17 & 0.667 & 12 & 0.672 & 15 \\
\hline 17 & $\begin{array}{l}\text { Negotiation of change orders by } \\
\text { knowledgeable persons }\end{array}$ & 0.452 & 17 & 0.50 & 16 & 0.427 & 17 & 0.512 & 17 \\
\hline 18 & $\begin{array}{l}\text { Improvement of management of } \\
\text { subcontractors to reduce conflicts and poor } \\
\text { coordination between the main and } \\
\text { subcontractors }\end{array}$ & 0.404 & 18 & 0.56 & 14 & 0.253 & 18 & 0.464 & 18 \\
\hline
\end{tabular}

Table 9 shows that based on the combined views of client in overall project, the major control measures to minimize variation orders are appointment of specified and appropriate competent project manager to supervise construction phases, preparation of bill of quantity with good estimate, full site investigation before and during construction, appointment of specified and appropriate competent project manager to supervise design and good relation and cooperation with project team members 
with RII $0.86,0.82,0.80,0.78$ and 0.74 respectively. The least important control measure is involvement of contractors during design phase with RII 0.42 .

Similarly, table 4.11 indicates that on the combined views of consultant in overall project, the major control measures to minimize variation orders are appointment of project manager to supervise design, close monitoring (timely monitoring mechanism), use of modern planning techniques (WBS, CPM, EVA etc.), appointment of specified and appropriate competent project manager to supervise construction phases and adequate financial planning with RII 0.96, 0.907, 0.853, 0.80 and 0.80 respectively. The least important control measure is improvement of management of subcontractors to reduce conflicts and poor coordination between the main and subcontractors with RII 0.253.

Similarly, table 9 reveals that on the combined views of contractor in overall project, the major control measures to minimize variations order are preparation of bill of quantity with good estimate, appointment of project manager to supervise design, adequate financial planning, thorough review of designs, drawings and plans and close monitoring (timely monitoring mechanism) with RII 0.92, 0.872, $0.856,0.840$ and 0.776 respectively. The least important control measure is improvement of management of subcontractors to reduce conflicts and poor coordination between the main and subcontractors with RII 0.464 .

Table 9 indicates that based on the analysis of the combined views of respondents' client, consultant and contractor in overall projects, it is found that best control measures to minimize variation orders are appointment of a specified and appropriate competent project manager to supervise design, preparation of bill of quantity with good estimate, adequate financial planning, close monitoring (timely monitoring mechanism) and use of modern planning techniques (WBS, CPM, EVA, etc.) with RII 0.88, 0.832, $0.808,0.776$ and 0.760 respectively. The least control measure to minimize variation order is improvement of management of subcontractors to reduce conflicts and poor coordination between the main and subcontractors with RII 0.404 .

The overall results indicate that the best control measure to minimize the variation order is to appoint a specified and appropriate competent project manager. All of the respondents emphasized that construction management is the major important factor to control the variation than other various factors.

The Spearman rank correlation of overall project with all 5 projects are calculated in table 47 to table 51 in appendices $C$ with result of $0.84,0.92,0.895,0.93,0.931$.for project 1 to project 5 respectively which shows that the data have strong relationship with each other.

\section{CONCLUSION :}

The project completion time of all of the building projects inside Tribhuvan University premises are found exceeded the contract project period. It is concluded that variation orders have increased the project cost. The major causes of variation orders impacting project cost are additional work, client financial problems/delay in payment of bill and change in design. Causes of variation orders impacting project time are change in design, delay in payment and dispute between parties to the contract. These major causes of variations are originated from the client and consultant. The contractor related causes of variation are lack of specified and appropriate competent construction manager, lack of involvement in design and lack of judgment and experience. it is seen that the major control measures to minimize the variation orders are appointment of specified and appropriate competent project manager to supervise design, preparation of bill of quantities with good estimate and adequate financial planning which impacted project completion time and cost of building construction inside Tribhuvan University premises.

Based on conclusions, Client should have a clear vision of the project, should carefully appoint expertise, should coordinate with other contracting parties. Consultant should be aware about the client's interest, avoid omissions in design, prepare good estimate. The contractor too should appoint efficient, appropriate project manager, use skilled manpower, should coordinate with client and consultant.

\section{ACKNOWLEDGEMENT :}

Thank God for giving such a great ability to MBMAN CM STUDENTS for staying at site and working such a hard and presenting as assignments also. 


\section{REFERENCES :}

[1] Mishra A. K., \& Thing R. (2019). Structural Features for Earthquake-Resistant Load-Bearing Residential Buildings in Nepal. J. Adv. Res. Geo. Sci. Rem. Sens, 6(1), 1-16.

[2] Mishra, A. K., (2020). Project Management: Theory and Practice from Different Countries. (p. 345). Tamilnadu: DK International Research Foundation. http://doi.org/10.5281/zenodo.4817542.

[3] Koirala N, Sharma P, Sapkota LK et al. (2021). Variations Order of Building Construction Project a Case from Nepal. J. Adv Res Const Urban Arch, 6(2): 25-33.

[4] Mishra, A. K., \& Aithal, P. S. (2020). Financial Impact Assessment of Time Overrun: A Case of Second Small Towns Water Supply and Sanitation Sector Project. Nepal International Journal of Applied Engineering and Management Letters (IJAEML), 4(2), 159-173.

[5] Ghimire, S. \& Mishra, A. K. (2019). Comparative Study of Prospective Delay Analysis Techniques (DATs). Saudi J Civ Eng., 3(5), 84-95.

[6] Yadav, S. K., \& Mishra, A. K. (2019). Status of Time and Cost Overrun of Health Building Construction Projects in Nepal. Sch J Eng Tech, 7(9), 262-270.

[7] Mishra, A. K., Sudarsan, J.S. \& Nithiyanantham, S. (2021). Assessment of time-cost model of public health buildings in Nepal. Asian J Civ Eng, 22(1), 13-22.

[8] Mishra, A. K., \& Aithal, P. S. (2020). Operation of price adjustment in construction projects. International Journal of Case Studies in Business, IT, and Education, 4(2), 229-49.

[9] Mishra A. K., \& Sharestha, M. (2017). Health and safety status of casual workers in road improvement project Kathmandu Valley, Nepal. International Journal of Engineering Technology Science and Research, 4(9), 1187-1199. 